u.s. DEPARTMEnt OF | Energy Efficiency \&

בN Jicy Renewable Energy

Challenges and Successes on the Path toward a Solar-Powered Community
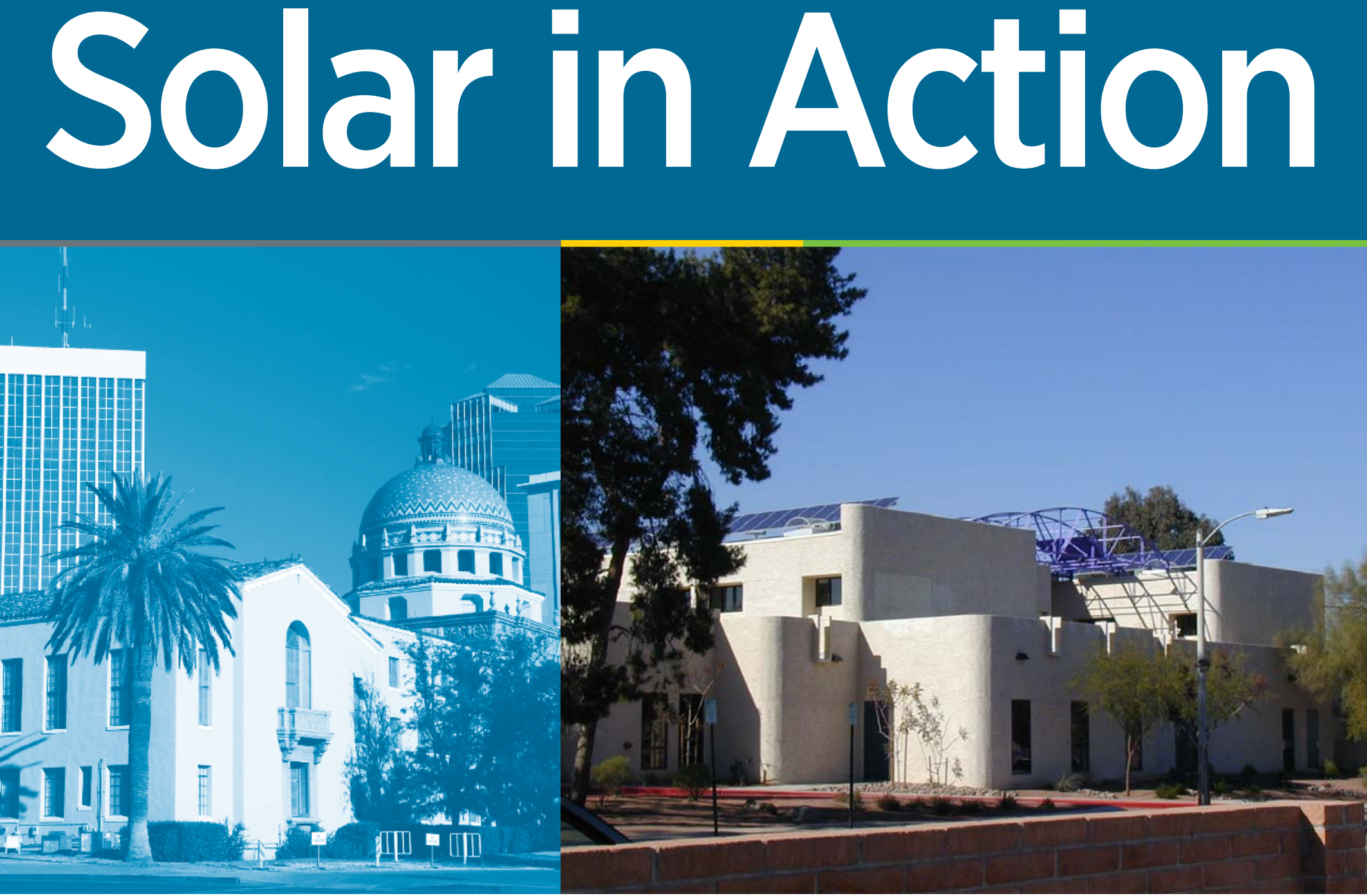

SOLAR AMERICA CITIES Fin

Part of the Solar America Communities program

\section{Tucson, Arizona}

Includes case studies on:

- Financing with Clean Renewable Energy Bonds

- Solar Ready Homes Ordinance

- Financing with Power Purchase Agreements 
- Transformation of knowledge market barriers into opportunities for solar energy installations.

One of the first and most important steps taken by Tucson was to hire a solar coordinator. With a solar coordinator, Tucson was able to take stock of its existing solar successes and formulate a plan for leveraging those successes into growing the local solar market. The solar coordinator also helped the city identify opportunities for partnerships and cultivate relationships with partners who could help the city reach its solar goals.

The following partners were involved with the Tucson Solar America Cities project:

- Arizona State Department of Commerce Energy Office

- Greater Tucson Coalition for Solar Energy

- Tucson Electric Power

- Tucson-Pima Metropolitan Energy Commission.

Tucson established the Southern Arizona Regional Solar Partnership as part of its comprehensive approach to advance solar market expansion and to remove local market barriers.

The partnership serves as a forum for coordinating a regional marketing strategy to advance solar power.

Tucson's Solar America Cities program focused its activities on bringing together local government officials, utilities, and private partners to streamline regulations, educate citizens, and increase large-scale solar installations on city buildings.

\section{Installed Capacity}

Tucson

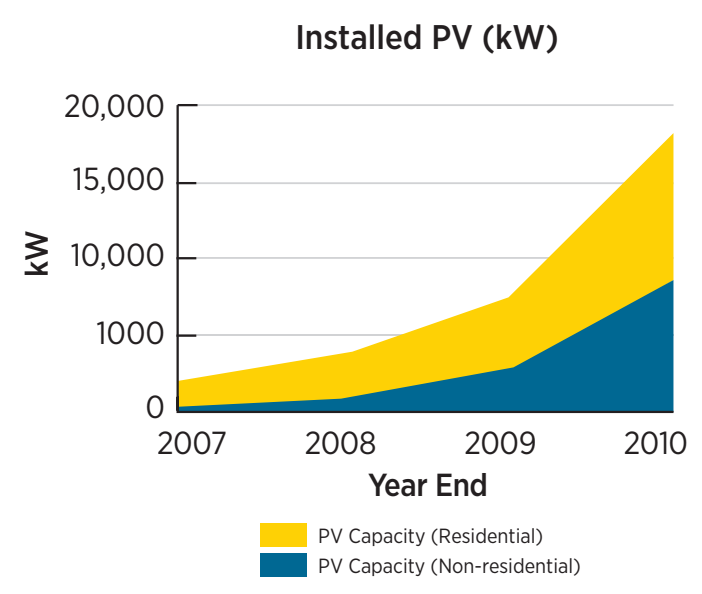

Installed PV capacity increase from December 31, 2007, to December 31, 2010

Key activities that the team identified to meet its overall solar goals were:

- Developing a City of Tucson Solar Energy Integration Plan and a Greater Tucson Solar Energy Development Plan

- Improving city regulations and building codes to help streamline the installation of solar systems

- Increasing the number of large-scale solar installations on city buildings. This was accomplished through the use of Clean Renewable Energy Bonds (CREBs) and Power

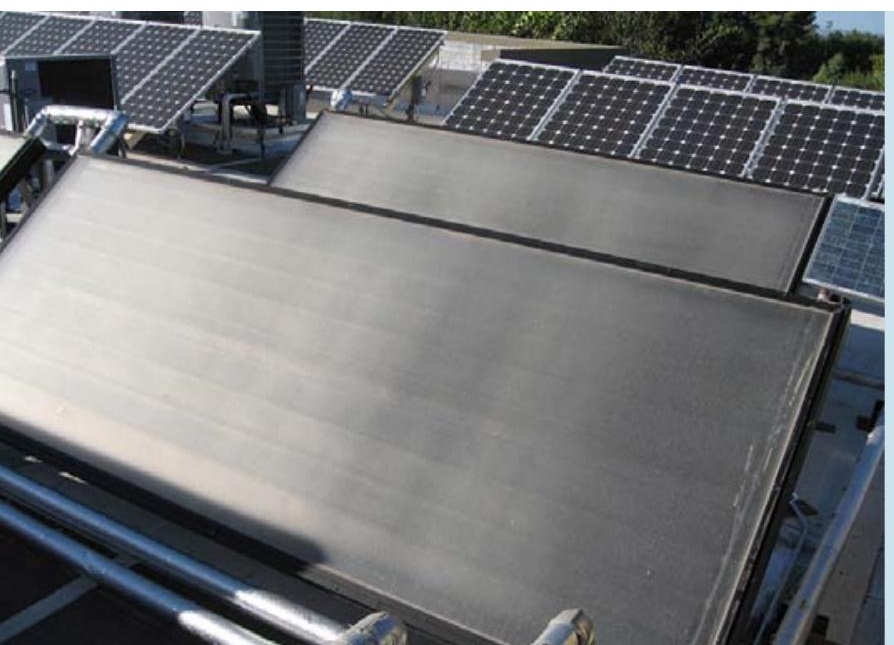

The Lee H. Brown Family Conservation Learning Center opened as Tucson's first Leadership in Energy and Environmental Design (LEED) Platinum-certified facility. Photo from The City of Tucson, NREL/PIX 18372 


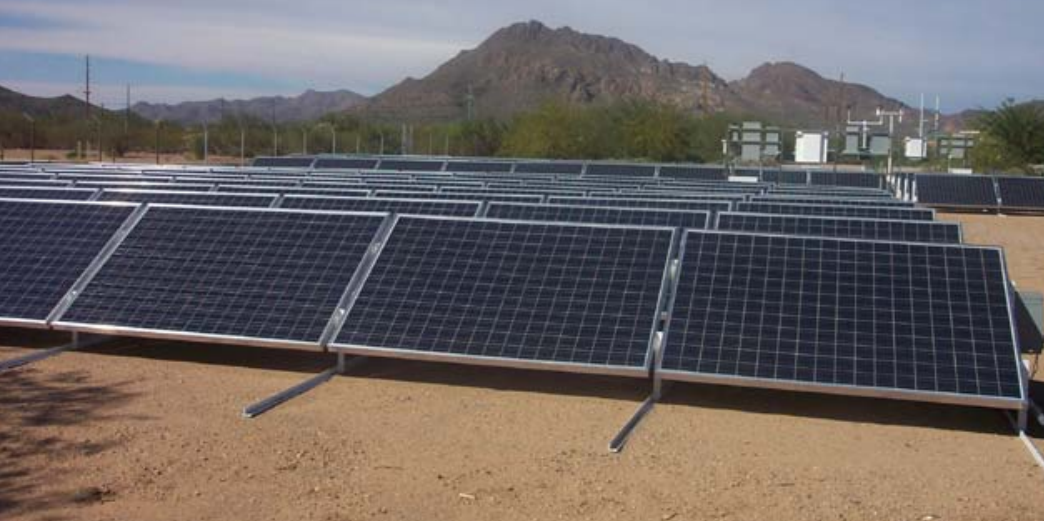

The Hayden-Udall Water Treatment Facility phase I array is the first City of Tucson solar project to take advantage of the many large parcels of land in the metropolitan area. Photo from The City of Tucson, NREL/PIX 18373

Purchase Agreement (PPA) financing programs to fund larger photovoltaic (PV) systems than the city had ever installed

- Forming new partnerships with local organizations designed to educate the Tucson community. This effort included frequent speaking opportunities with these organizations, as well as coordinating with U.S. Representative Gabrielle Giffords' office in their monthly Solar 101 presentations.

\section{Accomplishments and Highlights}

Unlike other Solar America Cities, Tucson focused the majority of its resources on developing large-scale solar installations. Highlights of Tucson's accomplishments include:

- Seven projects totaling $1 \mathrm{MW}$ were constructed in 2009 after the successful sale of nearly $\$ 8$ million in CREBs.

- Tucson Mayor Bob Walkup and the Tucson City Council adopted the Solar Ready Homes Ordinance for solar hot water and PV.

- A PPA to construct a 1-MW PV solar energy facility was negotiated and signed.

- The city worked with other local governments in the Tucson area to share relevant experience with solar financing and planning.

\section{Case Studies: Successes and Challenges}

\section{Financing with Clean Renewable Energy Bonds}

Tucson successfully developed and implemented a CREBs program, but not without some challenges. CREBs may be used by certain entities - primarily in the public sector - to finance renewable energy projects. The list of qualifying technologies is generally the same as that used for the federal renewable energy production tax credit.

CREBs may be issued by electric cooperatives, government entities (states, cities, counties, territories, Indian tribal governments, or any political subdivision thereof), and by certain lenders. CREBs are theoretically issued with a $0 \%$ interest rate. The borrower pays back only the principal of the bond, and the bondholder receives federal tax credits in lieu of the traditional bond interest.

For Tucson, there were few examples to follow for structuring a program that was favorable to the city. Eventually, Tucson was able to issue a 13-year bond that covered \$7.6 million for seven projects.

The city obtained authorization for these bonds from the IRS in 2006. They carry no interest charges but allow the purchaser to take a tax credit in lieu of interest to allow cities that are not eligible for the $30 \%$ federal solar investment tax credit to finance renewable energy projects.

Due to the unique nature of these bonds, the city was able to place them even in difficult economic times. City staff and advisors have worked since then to complete the transaction.

The seven projects will net the city more than \$3.4 million over the 25-year life of the solar equipment. The City of Tucson used the bond funds to expand its solar capacity from 220 kilowatts $(\mathrm{kW})$ to more than 1.2 MW.

The projects are located throughout Tucson, from the far southeast side at the Public Safety Training Academy to the Hayden Udall Central Arizona Project (CAP) Plant west of town, and include two neighborhood centers-El Pueblo and El Rio—as well as Tucson's Information Technology 
Building, a warehouse at Reid Park, and the Roger Road Reclaimed Water Reservoir.

At each location, the solar panels will produce electricity to cover a portion of the facility's electric load.

SPG Solar of Novato, California, installed the solar systems and will maintain them for 10 years under a service contract.

This is the first issuance of such bonds in the state of Arizona, although Sulphur Springs Valley Electric Cooperative in Wilcox, Arizona, received money from similar bonds issued by a national group of rural utilities last year and used the funds to pay for solar shade structures at schools.

\section{Solar Ready Homes Ordinance}

On June 17, 2008, the mayor and city council unanimously voted to require all new residences to be solar ready for electric (PV) and solar hot water. These rules are part of Tucson's effort to promote solar energy and reduce the amount of greenhouse gases produced by the city and its residents.

For PV, starting July 1, 2009, the rules required that all new single family homes or duplexes include a PV site plan for either installation of an actual PV system, or preparation for later installation of a PV system, in order to receive a building permit. This site plan must identify the best location(s) for a PV system, provide a roof structure strong enough to support the system, show an electrical load calculation for the system, and provide an electrical panel 240-volt circuit breaker labeled "reserved for photovoltaic."

For solar hot water, starting March 1, 2009, the rules required that all new single family homes or duplexes include in the plans either a solar hot water system or a stub out for later installation of a solar hot water system to receive a building permit. The water heater area must contain a $120-\mathrm{V}$ electrical receptacle and have sufficient room for an 80 -gallon water heater, an expansion tank, and a heat exchanger.

The Pennington Street Garage was the first city garage in Tucson to utilize solar power and was one of the first large-scale solar projects on a city facility. Photo from The City of Tucson, NREL/PIX 18374

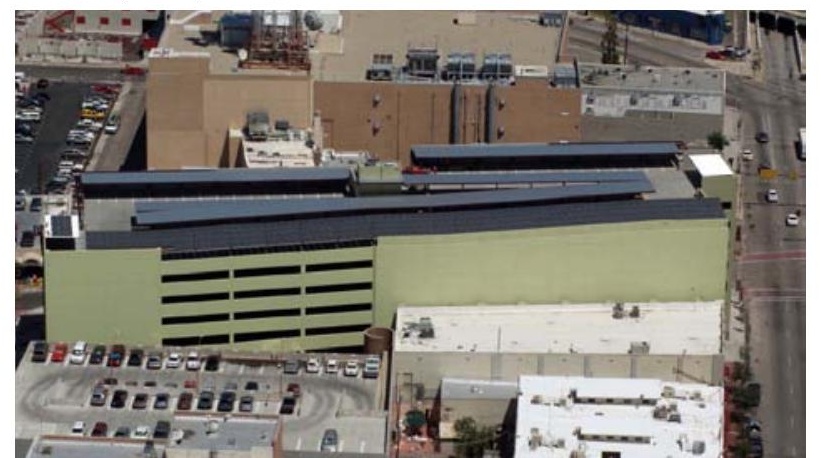

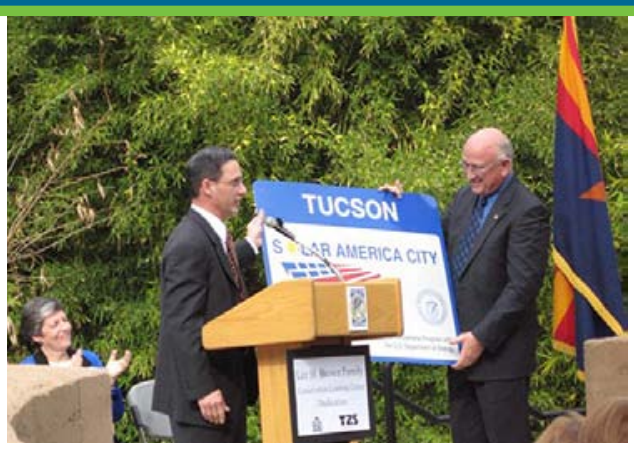

The partnerships developed through Tucson's participation in the Solar America Cities program were an important part of the city's success in promoting solar. Photo from Austin Energy, NREL/PIX 18402

\section{Financing with Power Purchase Agreements}

Tucson was able to negotiate and sign a PPA for the construction of a 1-MW solar energy plant adjacent to a Tucson Water facility. The city wanted to utilize this new method of financing to allow a comparison with the CREBs financing and determine the strengths and weaknesses of each of these methods. The third-party PPA model allows a developer to build and own a PV system on the customer's property and sell the power back to the customer (who avoids most or all initial costs, as well as operations and maintenance responsibilities). The customer can receive a guaranteed price of electricity over the life of the contract, typically 15-25 years. The most common pricing scheme is fixed price, but some PPAs use a fixed-escalator scheme, where the cost of electricity produced increases at a predetermined rate, usually $2 \%-5 \%$ over the life of the contract.

An important component of a PPA is negotiating an appropriate and fair contract. At the heart of the issue is whether the city writes the PPA itself, or accepts the PPA provided by the PV contractor. In Tucson's case, the city chose to use the PPA provided by the contractor, which had both positive and negative results. On the positive side, the city was able to use an existing contract that had been vetted and used by others in the industry. On the negative side, there were many PPA contract details that, in the end, were more favorable to the contractor than to the city. Unexpected costs related to insurance, inspections, and permitting arose that the city had to cover or deal with. In the final analysis, the city determined that the real lesson learned was that it should develop a city-specific PPA for all future engagements that would provide for favorable conditions for the city and an even playing field for contractor responses to requests for proposals. 


\section{Top Takeaways}

- For Tucson, recognition of the importance and value of partnerships was a key to the success of its solar program. From negotiating PPAs to developing ordinances for solar-ready homes, expertise shared by a variety of partners contributed greatly to increasing solar installations in Tucson.

- Encouraging solar on a tight budget is a challenge many cities face, and Tucson is continuing to successfully navigate this hurdle. By learning how to use creative financing and leveraging solar activities by others in and around Tucson, the city has been able to continue its solar program despite challenging financial times.

- Implementation of solar energy solutions by a city should be seen as an ongoing learning process. For example, as the city attempts to educate the population about solar technology and incentive programs, it is also educating itself about emerging technologies, policies, lessons learned, and best practices of other municipalities and organizations, as well as ever-changing incentive programs at the federal, state, and local levels. One enduring benefit of DOE's Solar America Cities program has been the knowledge sharing gained from the many meetings, conferences, and regional partnerships developed within the program. This network has greatly expedited the information sharing among the 25 cities and provided a boost to local programs.

\section{Next Steps}

Tucson developed groundbreaking solar financing models and streamlined solar permitting processes. New funding from the American Recovery and Reinvestment Act helps Tucson to scale up its most promising projects and concepts to overcome key barriers to urban solar energy use. As part of the Solar America Cities Special Projects funding, Tucson focuses on the following activities:

- Creative financing for municipal solar installationsTucson explores innovative financing mechanisms for solar systems on city facilities, including Build America Bonds, New Market Tax Credits, and partnership flipping.
Build America Bonds are taxable municipal bonds that carry special tax credits and federal subsidies for either the bond issuer or the bondholder. New Market Tax Credits are used to spur revitalization efforts of low-income and impoverished communities. Partnership flipping is a financing arrangement in which a renewable energy developer and tax investor become partners in the ownership of a project. Typically the tax investor makes a larger initial investment in the project in exchange for a larger share of the income that is generated from power sales and tax incentives. Once an agreed-upon rate of return is reached for the tax investor, the income stream "flips" and the developer earns the majority of the project income.

- Solar one-stop shop-The city partners with Pima County to establish and maintain a central location and website that provide information and referral services for consumers, businesses, and the solar industry, including training opportunities and permitting assistance.

- Solar integration into green building codes and infrastructure planningTucson coordinates with planning and permitting staff to integrate solar and solar-ready requirements into green building certification processes and long-range city infrastructure planning.

- Additional PPAs - The city creates more PPA projects for solar development and implementation in addition to the one already developed.

- Refinement to codes - Tucson will continue with additional changes to the city and county zoning and land use code to facilitate large-scale solar development.

- More standardized permitting processes-Tucson will simplify and unify permitting requirements for solar throughout the region. Because administrative or "balance of system" costs including permitting can make up approximately $40 \%$ of the cost of a solar system, streamlining these processes helps make solar more affordable.

- Attract the solar industry-The city continues efforts to draw solar manufacturers and installers to the area to provide for job growth and economic prosperity. 
